DOI https://doi.org/10.30929/2307-9770.2021.09.04.03

UDC 378.018.8:37.07-051]:005.336.2:004.9]:001.891

\title{
Study of managerial competence of future education managers in the context of using electronic educational environment
}

\author{
Stetsenko N., Tkachuk H. ${ }^{*}$ \\ Pavlo Tychyna Uman State Pedagogical University, Uman, Ukraine
}

Received: 05.11 .2021

Accepted: 22.12 .2021

\begin{abstract}
The article considers the question of the features of the training future education managers, their manage skills, the structure of which provides knowledge and experience in using the electronic educational environment. This problem is important, especially now, in the context of the coronavirus pandemic, when educational institutions work mainly in a distance format. Now every manager of an educational institution must be competent not only in the field of information technology and have appropriate digital competence but also knowledgeable in the implementation of the electronic educational environment of the institution, in particular, to resolve certain management issues. During literature analysis, we found that there are many studies that describe the use of ICT in the process of forming the managerial competence of future education managers. But, there are few studies that describe the features of the work of the manager in the electronic learning environment (ELE) and solve the problem of their training in this context. To obtain objective information about the level of managerial competence in future heads of higher pedagogical education, we organized a survey that found that future education managers do not have a clear idea of ELE and do not understand its potential for management. During the study, we developed levels of managerial competence of future managers, to which we added skills related to the use of ELE. The training of students lasted from 2017 to 2020 according to the methodology that took into account the structure of managerial competence knowledge and skills of using ELE. We conducted an experimental study that determined the effectiveness of the methodology for the formation of managerial competence of future heads of educational institutions in the context of ELE. This study found that such training contributes to the formation of the future manager, develops his managerial skills, allows to solve the problem of developing managerial competence in future education managers using ELE, is an effective means of implementing educational programs at the university.

Key words: managerial competence, manager of education, manager of educational institution, electronic educational environment, information and communication technologies, institution of higher education.
\end{abstract}

\section{Дослідження управлінської компетентності майбутніх менеджерів освіти в контексті використання електронного освітнього середовища}

\author{
Стеценко Н. М., Ткачук Г. В.
}

\author{
Уманський державний педагогічний університет імені Павла Тичини, Умань, Україна
}

\begin{abstract}
Анотація. В статті розглядається питання особливостей формування управлінської компетентності майбутніх менеджерів освіти, в структурі якої передбачено знання, вміння та досвід використання електронного освітнього середовища. Актуальність даної проблеми полягає в тому, що нині, в умовах пандемії, кожен керівник закладу освіти повинен бути компетентним не тільки в ссрері інформаційних технологій та мати відповідно цифрову компетентність, але й орієнтуватись у питаннях впровадження та реалізації електронного освітнього середовища закладу, зокрема для вирішення певних управлінських питань. В ході дослідження нами з'ясовано, що існує велика кількість досліджень щодо важливості ІКТ в структурі управлінської компетентності майбутніх менеджерів, проте практично відсутні роботи, які вивчають особливості організації діяльності менеджера в умовах впровадження електронного освітнього середовища (ЕОС). 3 метою отримання об'єктивної інформації про стан сформованості управлінської компетентності у майбутніх керівників закладів вищої педагогічної освіти нами було проведене анкетування, яке виявило, що майбутні менеджери освіти не мають чіткого уявлення про EOC та не розуміють його потенціал щодо управлінської діяльності. В ході дослідження було розроблено рівні управлінської сформованості управлінської компетентності майбутніх керівників, в яких передбачено уміння, що стосуються використання EOC.
\end{abstract}

Corresponding Author: Tkachuk Halyna Volodymyrivna. Phone: +380969169399. E-mail: tkachuk.g.v@udpu.edu.ua Pavlo Tychyna Uman State Pedagogical University, str. Sadova, 28, Uman, Cherkassy region, Ukraine, 20300.

Відповідальний автор: Ткачук Галина Володимирівна. Тел. +380969169399. E-mail: tkachuk.g.v@udpu.edu.ua Уманський державний педагогічний університет імені Павла Тичини, вул. Садова, Умань, 20300 
Підготовка фахівців здійснювалась впродовж 2017-2020 рр. за методикою, що враховувала у структурі управлінської компетентності знання та вміння використання ЕОС. Нами проведено експериментальне дослідження щодо ефективності методики формування управлінської компетентності майбутніх керівників закладів освіти з використанням ЕОС, яке показало, що використання ЕОС сприяє становленню майбутнього управлінця, розвиває його управлінські здібності, дає змогу вирішувати завдання формування управлінської компетентності у майбутніх менеджерів освіти, $€$ ефективним засобом реалізації освітніх програм в університеті.

Ключові слова: управлінська компетентність, менеджер освіти, керівник закладу освіти, електронне освітнє середовище, інформаційно-комунікаційні технології, заклад вищої освіти.

\title{
Исследование управленческой компетентности будущих менеджеров образования в контексте использования электронной образовательной среды
}

\author{
Стеценко Н. Н., Ткачук Г. В. \\ Уманский государственный педагогический университет имени Павла Тычины, Умань, Украина
}

\begin{abstract}
Аннотация. В статье рассматривается вопрос о особенностях формирования управленческой компетентности будущих менеджеров образования, в структуре которой предусмотрены знания, умения и опыт использования электронной образовательной среды. Актуальность данной проблемы состоит в том, что ныне, в условиях пандемии, каждый руководитель учебного заведения должен быть компетентным не только в сфере информационных технологий и иметь соответственно цифрровую компетентность, но и ориентироваться в вопросах внедрения и реализации электронной образовательной среды заведения, в частности для решения определенных управленческих вопросов. В ходе исследования нами выяснено, что существует большое количество исследований важности ИКТ в структуре управленческой компетентности будущих менеджеров, однако практически отсутствуют работы, изучающие особенности организации деятельности менеджера в условиях внедрения электронной образовательной среды (ЭОС). С целью получения объективной информации о состоянии сфрормированности управленческой компетентности у будущих руководителей заведений высшего педагогического образования нами было проведено анкетирование, которое выявило, будущие менеджеры образования не имеют ясного представления об ЭОС и не понимают его потенциал по управленческой деятельности. В ходе исследования были разработаны уровни управленческой сформированности управленческой компетентности будущих руководителей, в которых предусмотрены умения, касающиеся использования ЭОС. Подготовка специалистов осуществлялась на протяжении 2017-2020 гг. по методике, которая учитывала в структуре управленческой компетентности знания и умение использования ЭОС. Нами проведено экспериментальное исследование эфффективности методики формирования управленческой компетентности будущих руководителей учебных заведений с использованием ЭОС, которое показало, что использование ЭОС способствует становлению будущего управленца, развивает его управленческие способности, позволяет решать задачи формирования управленческой компетентности у будущих менеджеров образования, является эффективным средством образовательных программ в университете.

Ключевые слова: управленческая компетентность, менеджер образования, руководитель учебного заведения, электронная образовательная среда, информационно-коммуникационные технологии, заведение высшего образования.
\end{abstract}

\section{Bcmyn}

Інфрормаційно-комунікаційні технології у всьому світі визнані ключовими технологіями XXI століття, що на найближчі десятиріччя будуть основними рушійними силами науково-технічного прогресу. Інформатизація освіти $є$ частиною цього глобального процесу. Актуальною проблемою сьогодення є розробка таких освітніх технологій, які здатні модернізувати традиційні форми управління навчальним закладом із метою підвищення рівня організації освітнього процесу. Про це йдеться у Концепції Нової української школи [6]: «Педагогіка партнерства і компетентнісний підхід потребують нового освітнього середовища. Таке середовище допомагає створити новітні інформаційнокомунікаційні технології, які підвищують ефективність управління освітнім процесом, а водночас уможливлюють індивідуальний підхід до навчання». Про актуальність навичок в сфері ІКТ йдеться і в Європейській рамці цифррової компетентності [11], де цифрова компетентність визначена як діяльність, що передбачає впевнене, критичне й відповідальне використання та взаємодію з цифровими 
технологіями для отримання освіти, професійної діяльності та загалом для життя у суспільстві.

Питання впровадження інформаційно-комунікаційних технологій в управління закладом освіти залишається актуальним і нині серед наукової спільноти. Зокрема, Тимофєєва І.Б., Мітін А.О. вивчали теоретичний аспект формування цифрової компетентності майбутнього менеджера освіти [10]; Брик Р.С. досліджував питання використання ІКТ в управлінській діяльності освітнього закладу [2]; Кірдан О.Л. розглянула питання формування цифрових компетентностей у змісті підготовки магістрів освітньопрофресійної програми «Управління закладом освіти» [5]; Гребеник І.С. розглядала особливості цифрової компетентності керівників та принципи її формування [3]. Аналіз праць фахівців дозволяє стверджувати, що попри детальне вивчення вище зазначених аспектів проблеми, питання професійної інтерпретації діяльності менеджера освіти за підтримки IKT та в контексті використання ЕОС закладу освіти розроблено недостатньо. Зокрема, відсутні дослідження, що стосуються особливостей формування управлінської компетентності в контексті використання електронного освітнього середовища.

Мета нашої роботи є дослідження управлінської компетентності майбутніх менеджерів освіти в контексті використання ЕОС, а саме у визначенні стану її сфрормованості, описі її рівнів та проведенні діагностики у майбутніх фрахівців.

\section{II Матеріал і методи дослідження}

3 метою отримання об'єктивної інформації про стан сфрормованості управлінської компетентності у майбутніх керівників закладів вищої педагогічної освіти нами було проведене анкетування серед магістрантів Уманського державного педагогічного університету імені Павла Тичини на початку першого року їх навчання у магістратурі. Учасниками були студенти I курсу 2018-2019 рр. навчання та 2019-2020 pp. навчання. Завдання анкетування полягало в тому, щоб отримати інформацію про розуміння студентами поняття «електронне освітнє середовище», визначити як майбутні керівники будуть його використовувати при вирішенні управлінських завдань, їх ставлення до застосування в управлінському процесі різних програмних засобів, тощо.

В анкетуванні брали участь 37 магістрантів очної та заочної форм навчання, які навчалися за освітньо-професійною програмою «Управління навчальним закладом» за спеціальністю 073 «Менеджмент» галузі знань 07 Управління та адміністрування [7]. Оскільки майбутні менеджери освіти мали краще уявлення про діяльність керівника закладу загальної середньої освіти (33СО), директора школи, ніж керівників інших типів освітніх закладів, то питання анкети, в основному, були спрямовані на виявлення розуміння студентами-магістрантами управлінської компетентності керівника закладу загальної середньої освіти, його управлінських функцій, розподілу повноважень та впливу на учасників освітнього процесу, а також використання електронного освітнього середовища у діяльності управлінця.

Анкетування проходило в умовах традиційного навчання магістрантів, які ще не були приєднані до курсів дисциплін, комплекс яких розміщений в освітньому середовищі Уманського державного університету імені Павла Тичини (на базі системи управління навчанням Moodle).

Майбутнім управлінцям пропонувалося дати відповідь на питання анкети. Проаналізуємо відповіді магістрантів.

Відповіді на питання «Що ви розумієте під електронним освітнім середовищем?» (рис. 1) розподілилися таким чином: 16,2\% під електронним освітніх середовищем (EOC) розуміють організовану сукупність інформаційного, технічного, навчально-методичного забезпечення у вигляді технічних і програмних засобів накопичення, зберігання, обробки та передачі інформації, що забезпечує оперативний доступ до навчальних ресурсів, загалом правильно. 13,6\% майбутніх управлінців вважають, що ЕОС $є$ умовою, яка дозволить досягнути високої якості освіти. Для 18,9\% респондентів EOC $є$ не просто умовою, а сукупністю всіх умов та фракторів, що впливають на розвиток особистості, а для 24,3\% - педагогічними умовами, що забезпечують розвиток дитини, тобто майже $57 \%$ майбутніх управлінців вбачають у ЕОС умови, які сприяють та забезпечують розвиток особистості. Більш, ніж четверта частина (27\%) студентів-магістрантів взагалі вважають, що EOC - це психологічна атмосфера закладу освіти. Під час бесіди зі студентами з'ясувалося, що вони розуміють використання ЕОС для навчання дітей з особливими освітніми потребами та можливістю уникнути булінгу зі сторони учнів 
класу, оскільки за допомогою ЕОС можуть працювати дистанційно: «...і їм добре, і не заважатимуть учителю і учням у класі» - такою була відповідь.

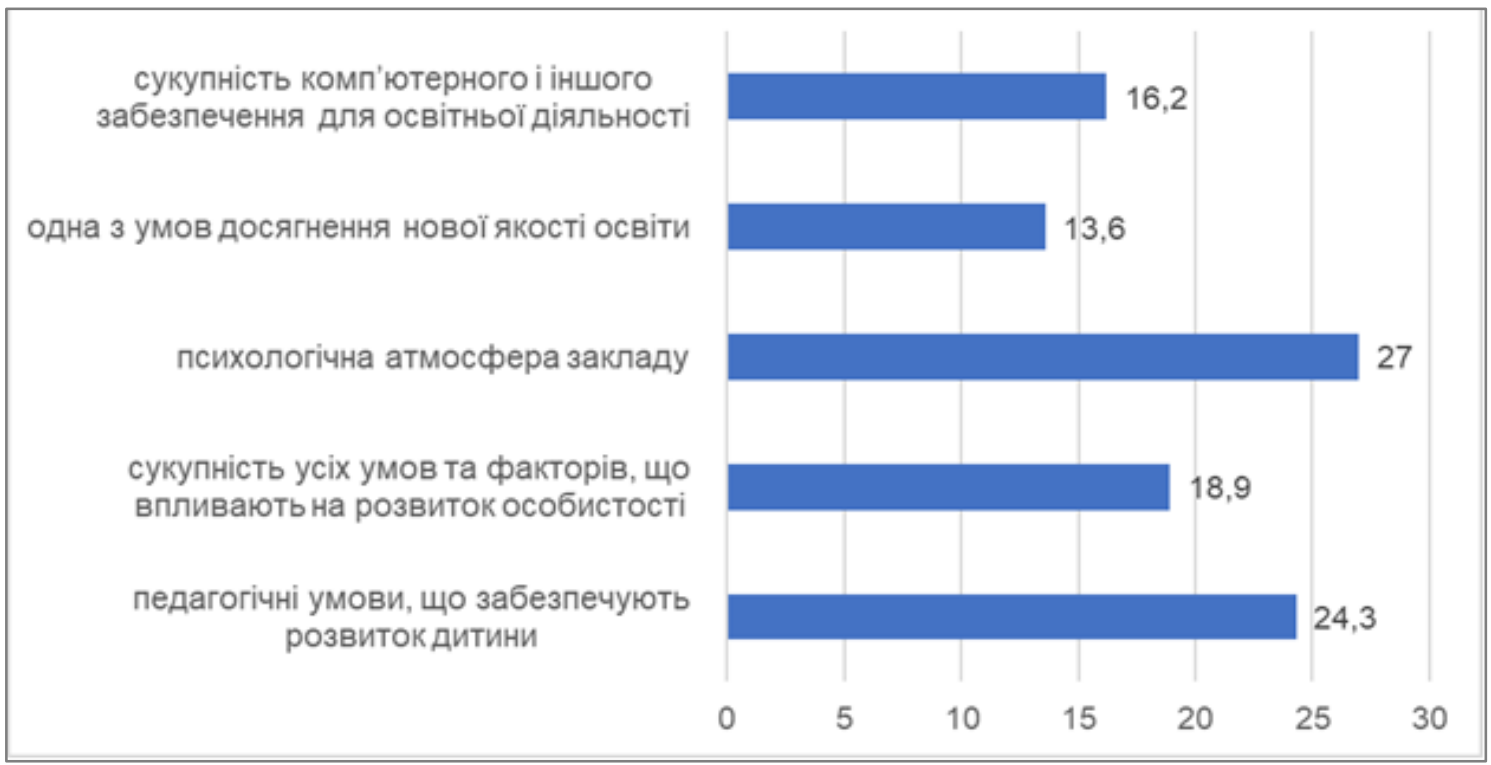

Рис. 1. Що ви розумієте під електронним освітнім середовищем?

На питання «Якому із способів чи засобів ви, як майбутній управлінець, надаєте перевагу для проведення наради серед своїх підлеглих в екстремальних умовах?» (рис. 2) 46\% майбутніх менеджерів відповіли, що скоріше за все скористалися б телесоном і зібрали учасників освітнього процесу на нараду, повідомивши місце і час зібрання.

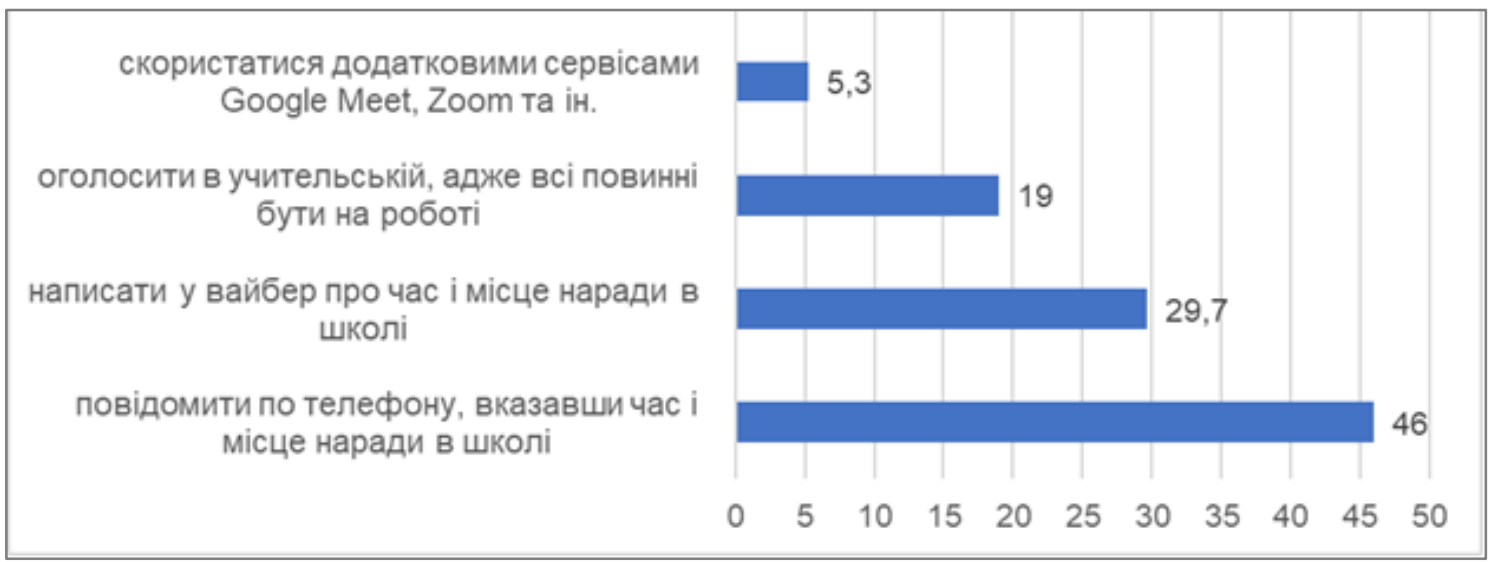

Рис. 2. Якому із способів чи засобів ви, як майбутній управлінець, надаєте перевагу для проведення наради серед своїх підлеглих в екстремальних умовах?

29,7\% студентів-магістрантів вирішили, що найкраще скористатися месенджером (Viber) і призначити нараду у відповідному місці і у відповідний час. 19\% майбутніх управлінців взагалі вважають, що всі педагогічні працівники повинні бути на роботі і в будь-який час бути готовими зібратися на нараду. I лише 5,3\% майбутніх менеджерів освіти завважили, що найкращим виходом в умовах екстреної ситуації буде використання сервісів для проведення відеоконференцій та нарад.

Наступне питання випливало із попереднього і стосувалося потреби керівника закладу загальної середньої освіти в оволодінні вміннями користуватися сервісами для проведення відеоконференцій. Відповіді респондентів виявилися дещо несподіваними (рис. 3). 


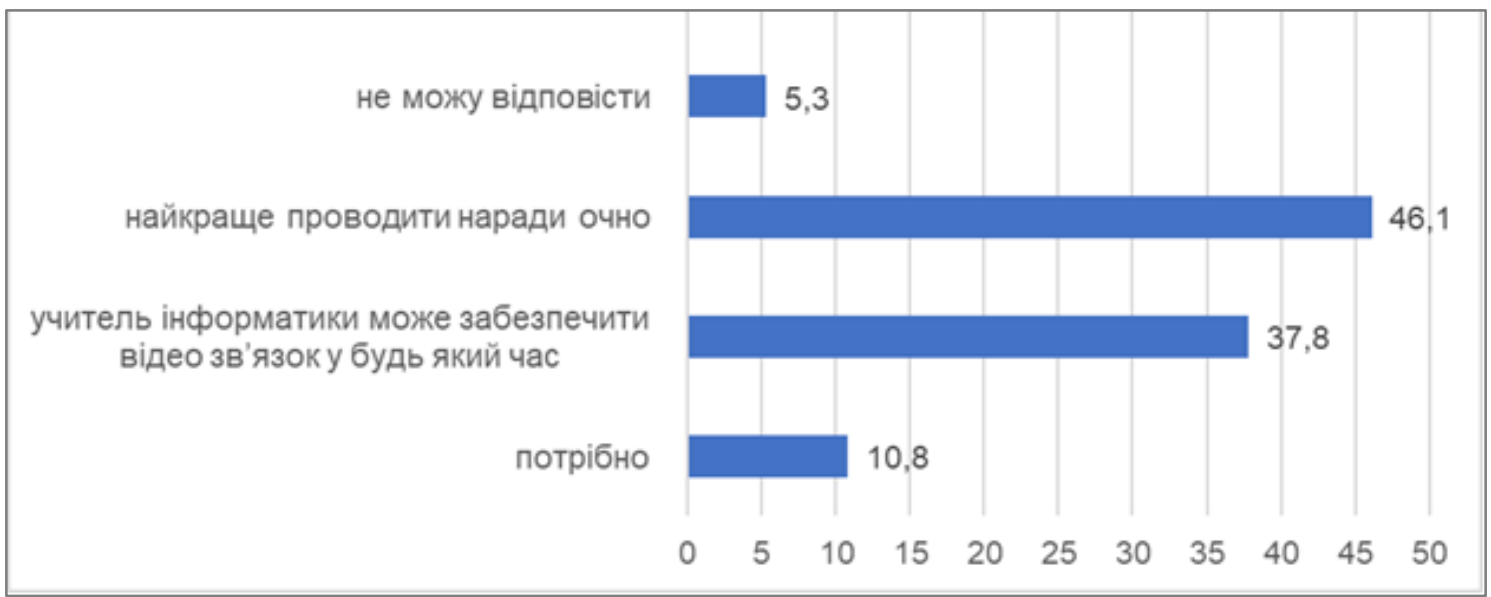

Рис. 3. Чи потрібно керівнику 33СО вміти користуватися сервісами для ведення відеоконференцій?

Так, 46,1\% майбутніх управлінців вважають, що наради найкраще проводити очно, тому особливої потреби оволодіти такими вміннями керівник не має. Ще 37,8\% респондентів також вважають, що керівник освітнього закладу, в даному випадку директор школи, завжди може скористатися послугами вчителя інформатики, якщо в цьому виникне потреба (хоча в обов'язки учителя інформатики забезпечення відеозв'язку для директора школи це не входить). Твердо вважають, що директор школи повинен вміти використовувати хоча б один сервіс для здійснення відеозв'язку 10,8\% майбутніх управлінців. Не змогли відповісти на це питання 5,3\% магістрантів, яким жодна із відповідей не підійшла, а власну сформулювати вони не змогли.

Виявити, наскільки майбутні менеджери освіти усвідомлюють можливості EOC в здійсненні управлінської діяльності дало змогу наступне питання (рис. 4).

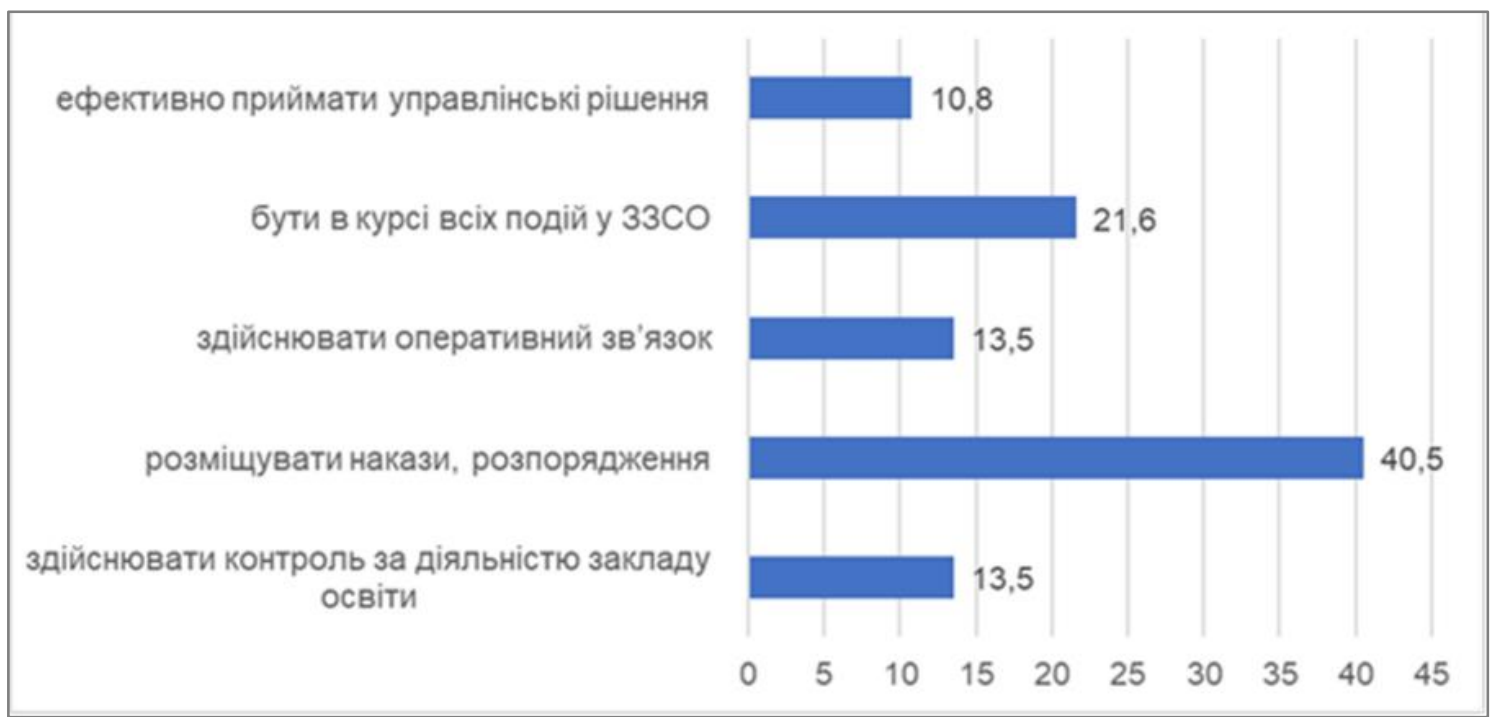

Рис. 4. Які можливості для керівника освітнього закладу відкриває електронне освітнє середовище?

Як видно з діаграми, 40,5\% респондентів вважають, що EOC закладу освіти є дуже зручним і важливим для розміщення наказів та розпоряджень, іншої документації, що стосується діяльності освітнього закладу. Однакова кількість майбутніх управлінців (по 13,5\%) можливості ЕОС вбачають у здійсненні оперативного зв'язку з учасниками освітнього процесу та здійсненні контролю за діяльністю закладу освіти. 21,6\% магістрантів прагнуть використовувати у своїй управлінській діяльності ЕОС для того, щоб бути в курсі всіх подій, які відбуваються у закладі освіти, як от: діяльність класних керівників, вчителів-предметників, методоб'єднань, учнівського самоврядування, тощо. Лише 10,8\% майбутніх менеджерів освіти вважають, що ЕОС дасть можливість ефективно приймати управлінські рішення. 
Враховуючи те, що назріла необхідність не лише у закладах вищої освіти впроваджувати дистанційну форму здобуття освіти, а і у $33 \mathrm{CO}$ (стаття 8 Закону України «Про освіту»: «п. 3. Заклади загальної середньої освіти можуть створювати у своєму складі класи (групи) з вечірньою (заочною), дистанційною формою навчання, класи (групи) з поглибленим вивченням окремих предметів, спеціальні та інклюзивні класи для навчання дітей з особливими освітніми потребами» [4], магістрантам було запропоновано дати відповідь на питання про дистанційні технології навчання (рис. 5).

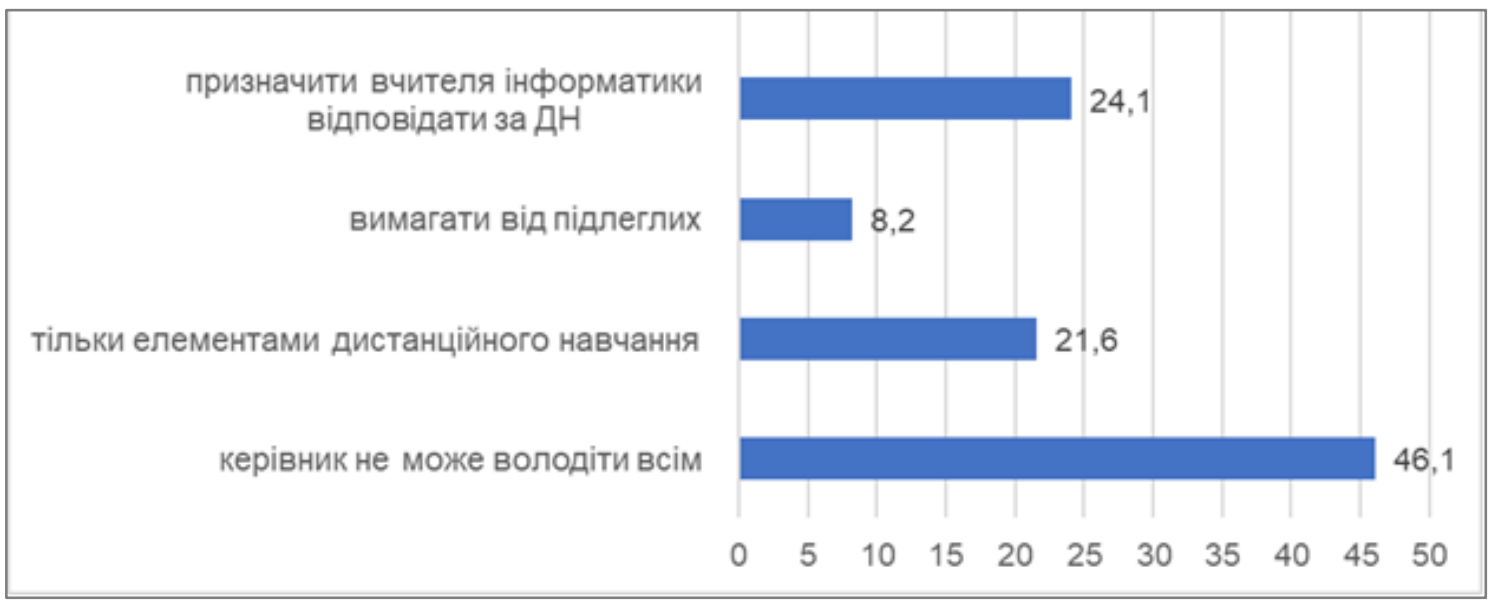

Рис. 5. Чи потрібно керівнику З3СО володіти технологіями дистанційного навчання?

Відповіді на це питання розподілилися так: значна частина майбутніх керівників закладів освіти $(46,1 \%)$ схиляються до думки, що керівник не може оволодіти всіма інформаційними технологіями, його завдання керувати. 21,6\% респондентів вважають, що якщо директор школи оволодіє деякими елементами дистанційного навчання, то цього йому досить, щоб організувати в школі дистанційне навчання, адже він його безпосередньо здійснювати не буде. Пропонують призначити відповідати за здійснення дистанційного навчання учителя інформатики $24,1 \%$ респондентів, очевидно не розуміючи, що такого розпорядження директор школи дати не може в силу обмеження своїх управлінських функцій, a 8,2\% майбутніх керівників будуть вимагати від підлеглих (учителів школи) оволодівати технологіями дистанційного навчання для здійснення навчання дітей з особливими потребами.

Враховуючи те, що МОН України активно працює над створенням електронних освітніх платформ для 33СО, майбутнім управлінцям було запропоновано назвати основні умови для створення ЕОС закладу $3 \mathrm{CO}$ (рис. 6).

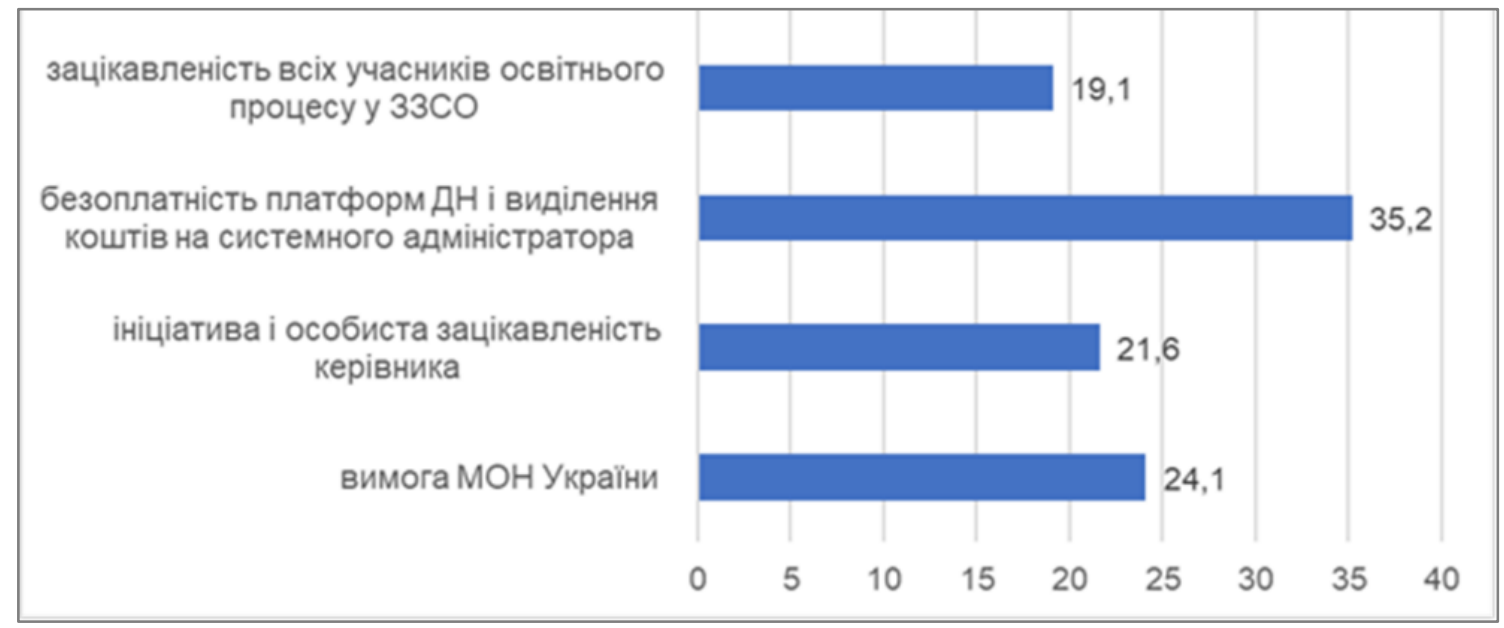

Рис. 6. Які основні умови створення у школі ЕОС? 
Як видно з діаграми, значна частина $(35,2 \%)$ майбутніх управлінців розуміють, що хороша і багатофункціональна платформа для дистанційного навчання $€$ дорогою та потребує спеціального обслуговування, відповіли, що основною умовою створення ЕОС у З3СО є безоплатність платформ дистанційного навчання і виділення коштів на системного адміністратора. $24,1 \%$ респондентів вважають, що це має бути вимога МОН України і воно (Міністерство) повинно подбати про можливість використання ЕОС. Ініціативі і особистій зацікавленості надають перевагу 21,6\% майбутніх керівників, а 19,1\% - зацікавленості всіх учасників освітнього процесу 33 СО.

Наступне питання мало на меті з'ясувати думку майбутніх менеджерів освіти щодо рівня впливу ЕОС на формування їх управлінської компетентності (рис. 7).

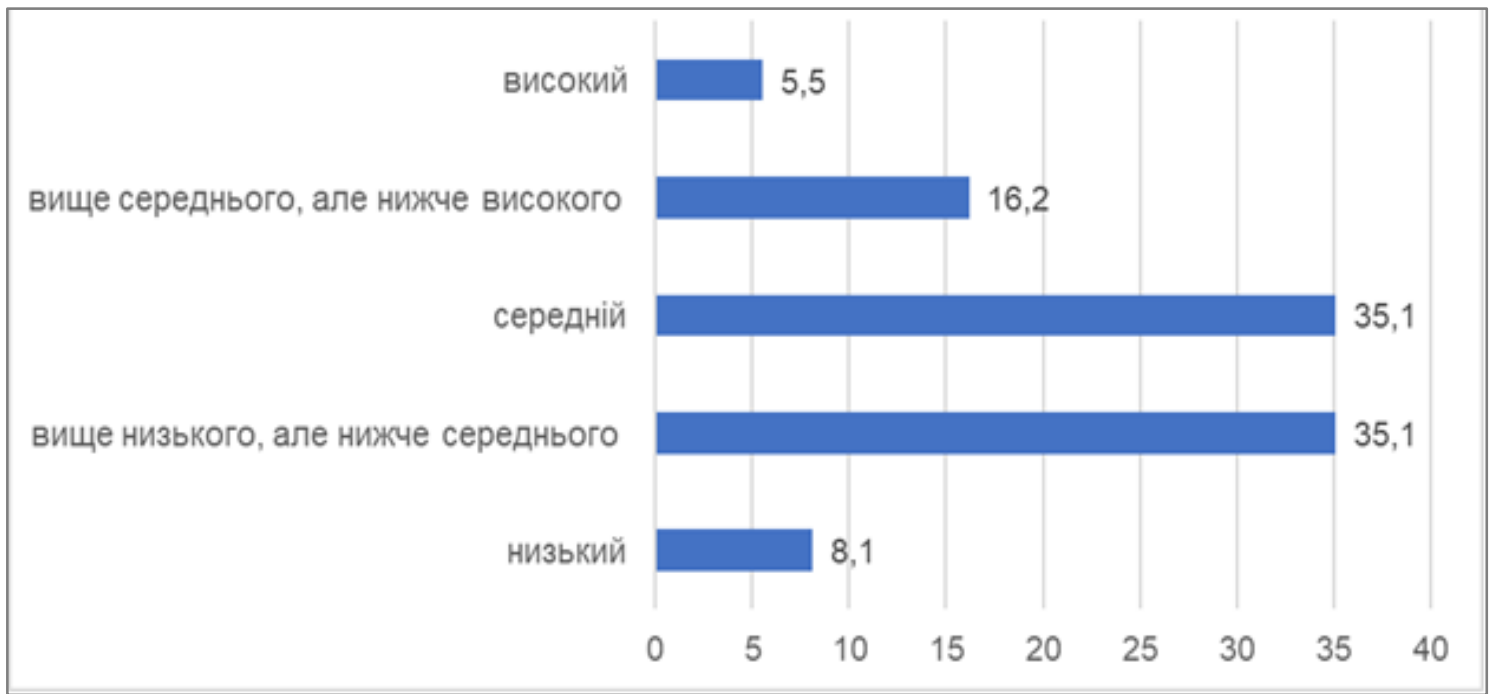

Рис. 7. Який, на Вашу думку, рівень впливу ЕОС на формування управлінської компетентності керівника 33CO?

Значна частина респондентів, 70,2 \% вважають, що вплив EOC на фрормування управлінської компетентності керівника $є$ середнім $(35,1 \%)$ або вище низького, але нижче середнього $(35,1 \%)$; як низький рівень відмічають 8,1\% респондентів; більше п'ятої частини (21,7 відсотка) майбутніх менеджерів освіти впевнені, що рівень впливу EOC на формування управлінської компетентності високий (5,5\%) або вище середнього, але нижче високого (16,2\%).

Обробка результатів анкетування, яке проводилося серед студентів-магістрантів на початку першого року навчання дала змогу встановити, що майбутні менеджери освіти не мають чіткого уявлення про EOC, не всі розуміють управлінські функції керівника закладу освіти, губляться в питаннях, що стосуються використання EOC в управлінській діяльності; рівень впливу ЕОС, в основному, оцінюють як низький та середній, що свідчить про необхідність підвищення їх управлінської компетентності засобами IKT, включити до роботи в ЕОС університету та стимулювати їх активність в даному середовищі, показавши роль і значення використання EOC в їх майбутній управлінській діяльності.

\section{III Результати}

На основі проведеного анкетування та аналізу літератури щодо управлінської компетентності майбутніх керівників закладів освіти нами було розроблено 4 рівні (високий, достатній, задовільний і низький) сформованості управлінської компетентності майбутніх управлінців, які мають комплексний характер і дають системне уявлення про управлінську компетентність майбутнього менеджера освіти як інтегрованого особистісного утворення педагога. Особливістю визначених рівнів $є$ те, що вони враховують знання та уміння менеджера закладу освіти використовувати EOC в 33СО для управлінських процесів.

До високого рівня сформованості управлінської компетентності у студентів-магістрантів було віднесено розуміння ролі та значення визначення перспективи освітнього закладу, чіткого усвідомлення 
управлінської місії; глибоке усвідомлення сутності, принципів, етапів розвитку освітнього закладу, законів, що забезпечують його функціонування; знання основних засад функціонування ЕОС та вміння його використання для реалізації управлінських процесів; знання культури прийняття управлінських рішень, стилів реалізації процесу прийняття управлінських рішень; суті, переваг делегування завдань і повноважень; проявляє лідерські якості у процесі організованої групової роботи під час занять, вміє характеризувати та аналізувати ступінь впливу зовнішніх та внутрішніх факторів на діяльність закладу освіти; демонструє знання методики та засобів планування, проектування, інфрормаційного моделювання управлінських процесів у закладі освіти; виявляє навички оцінювання ефективності діяльності учасників освітнього процесу та освітнього закладу загалом.

Достатній рівень сформованості управлінської компетентності у майбутніх менеджерів освіти характеризувався розумінням ролі та значення перспективи освітнього закладу, знаннями теоретичних основ планування, організації та управління освітнім закладом, основ організації внутрішнього керівництва, контролю та методичної роботи; при підтримці викладача може продемонструвати вміння моделювати процес управління освітнім закладом, використовувати ЕОС для ефективного управління; має навички аналізу і структурування проблем закладу освіти і розробляти рішення; теоретичний рівень підготовки дещо нижчий за практичний. Разом з тим, має виражені лідерські якості, вміє встановлювати причинно-наслідкові зв'язки під час вирішення конфліктних ситуацій, під час проходження управлінської практики має достатній рівень застосування набутих теоретичних знань.

Задовільний рівень сформованості управлінської компетентності у майбутніх керівників закладів освіти характеризувався посередніми теоретичними знаннями щодо місії освітньої установи, перспектив іï розвитку, магістрант не вміє швидко визначати структуру освітнього закладу, педагогічно доцільно планувати і організовувати власну педагогічну діяльність; EOC університету використовує для опрацювання навчального матеріалу з дисципліни; має слабкі навички моделювання управлінських процесів у закладі освіти з використанням EOC; не володіє явно вираженими організаторськими здібностями, погано розбирається в обов'язках адміністративно-управлінського персоналу школи.

Низький рівень сформованості управлінської компетентності у майбутніх управлінців характеризувався слабким розумінням теоретичних засад управлінської діяльності, ролі керівника у формуванні психологічного клімату закладу освіти, не має достатніх теоретичних знань та умінь моделювання управлінських процесів у закладі освіти з використанням EOC, демонструє слабкі організаторські здібності, в командній роботі здебільшого займає роль спостерігача.

На початку проведення експерименту (навчання магістрів за освітньою програмою «Управління закладом освіти» зі спеціальності 073 «Менеджмент») було зроблено зріз за визначеними рівнями сформованості управлінської компетентності майбутніх менеджерів освіти серед магістрантів 2017-2018 рр. вступу та 2018-2019 років вступу в Уманський державний педагогічний університет імені Павла Тичини (табл. 1).

Таблиця 1. Рівні сфформованості управлінської компетентності у магістрантів на початок навчання (рік вступу в магістратуру)

\begin{tabular}{|l|c|c|c|c|c|c|c|c|}
\hline \multirow{2}{*}{ Рік навчання } & \multicolumn{2}{|c|}{ Високий } & \multicolumn{2}{|c|}{ Достатній } & \multicolumn{2}{|c|}{ Задовільний } & \multicolumn{2}{|c|}{ Низький } \\
\cline { 2 - 13 } & осіб & $\%$ & осіб & $\%$ & осіб & $\%$ & осіб & $\%$ \\
\hline 2017-2018 (експериментальна група: 19 осіб) & 1 & 5,3 & 4 & 21 & 5 & 26,3 & 9 & 47,4 \\
\hline 2018-2019 (контрольна група: 18 осіб & 1 & 5,6 & 5 & 27,7 & 4 & 22,4 & 8 & 44,3 \\
\hline
\end{tabular}

Аналіз таблиці 1 дав змогу встановити, що в контрольній і в експериментальній групах рівень сформованості управлінської компетентності дещо відрізняються, що пов'язано з кількістю студентів та рівнем підготовки магістрантів, які вступали у різні роки на навчання. Загалом же, рівень сформованості управлінської компетентності в обох групах характеризується як задовільний та низький. 
Зрозуміло, що майбутні менеджери освіти ще не відчували себе у ролі керівників, не були знайомі з особливостями управлінської діяльності, нормативно-правовою базою, хоча знання з теорії і практики дисциплін психолого-педагогічного блоку дали можливість сформувати відповідні якості і властивості, притаманні майбутньому управлінцю.

Випускники 2019-2020 року вступу в Уманський державний педагогічний університет імені Павла Тичини, на відміну від випускників попередніх років, зіткнулися з проблемою дистанційного та змішаного навчання, яка виникла внаслідок поширення коронавірусної інфекції COVID-19. MOH України було розроблено Рекомендації щодо впровадження змішаного навчання у закладах фрахової передвищої та вищої освіти [8].

Дана ситуація спонукала науково-педагогічних працівників університету більш активно розвивати та наповнювати ЕOC, використовувати різні сервіси для відеозанять, інноваційні форми та методи роботи [1], а студентів - активно включитися у освітній процес і більш широко використовувати ЕОС університету, збагнути роль та значення ЕОС для ефективного здійснення різного роду діяльності, в тому числі, управлінської, що, безумовно, вплинуло на формування управлінської компетентності майбутніх керівників. Опис окремих методичних аспектів підготовки фахівці в умовах використання EOC та формування в них відповідної управлінської компетентності детально описано нами у роботі [9].

Для виявлення стану сформованості управлінської компетентності у майбутніх менеджерів освіти на кінець другого року навчання нами був проведений зріз за розробленими рівнями (табл. 2).

Таблиця 2. Рівні сформованості управлінської компетентності у майбутніх менеджерів освіти на кінець експерименту

\begin{tabular}{|l|c|c|c|c|c|c|c|c|}
\hline \multirow{2}{*}{ Рік навчання } & \multicolumn{2}{|c|}{ Високий } & \multicolumn{2}{|c|}{ Достатній } & \multicolumn{2}{|c|}{ Задовільний } & \multicolumn{2}{|c|}{ Низький } \\
\cline { 2 - 9 } & осіб & $\%$ & осіб & $\%$ & осіб & $\%$ & осіб & $\%$ \\
\hline $\begin{array}{l}\text { 2019-2020 } \\
\text { (експериментальна група: 19 осіб) }\end{array}$ & 3 & 15,8 & 10 & 52,7 & 5 & 26,3 & 1 & 5,2 \\
\hline $\begin{array}{l}\text { 2018-2019 } \\
\text { (контрольна група: 18 осіб) }\end{array}$ & 2 & 11,1 & 7 & 38,9 & 7 & 38,9 & 2 & 11,1 \\
\hline
\end{tabular}

Як видно із таблиці, результати сфрормованості управлінської компетентності у студентівмагістрантів експериментальної групи дещо вищі порівняно із студентами-магістрантами контрольної групи. Так, високим рівнем управлінської компетентності на кінець навчання (кінець 2020 року) володіють 15,8\% майбутніх менеджерів освіти, що на 4,9 відсотків більше, порівняно з майбутніми менеджерами, які закінчували навчання у 2019 році $(11,1 \%)$. Студенти експериментальної групи оволоділи навичками роботи в ЕОС університету, почали більше займатися самостійно, нові форми роботи виявилися більш цікавими та інформативними. В процесі проходження управлінської практики, вони також зіткнулися з проблемою управлінської діяльності за допомогою електронних платформ і сервісів для проведення оперативних нарад, конференцій та відеозв'язку з учасниками освітнього процесу.

Достатній рівень сфрормованості управлінською компетентністю у майбутніх управлінців експериментально групи теж зріс на 13,8\% порівняно із контрольною групою. Якщо високий і достатній показники рівнів сформованості управлінської компетентності експериментальної групи майбутніх управлінців на кінець навчання зросли, то показники задовільного та низького рівнів зменшилися. Так, задовільним рівнем сформованості управлінської компетентності на кінець навчання володіють 26,3\% магістранти експериментальної групи, що на 12,6\% менше, ніж у магістрантів контрольної групи (38,9\%); низький рівень сфрормованості управлінської культури також зменшився на 5,9 відсотки.

Результати заключного зрізу щодо визначення рівня сформованості управлінської компетентності майбутніх менеджерів освіти наочно представлений на рис. 8. 


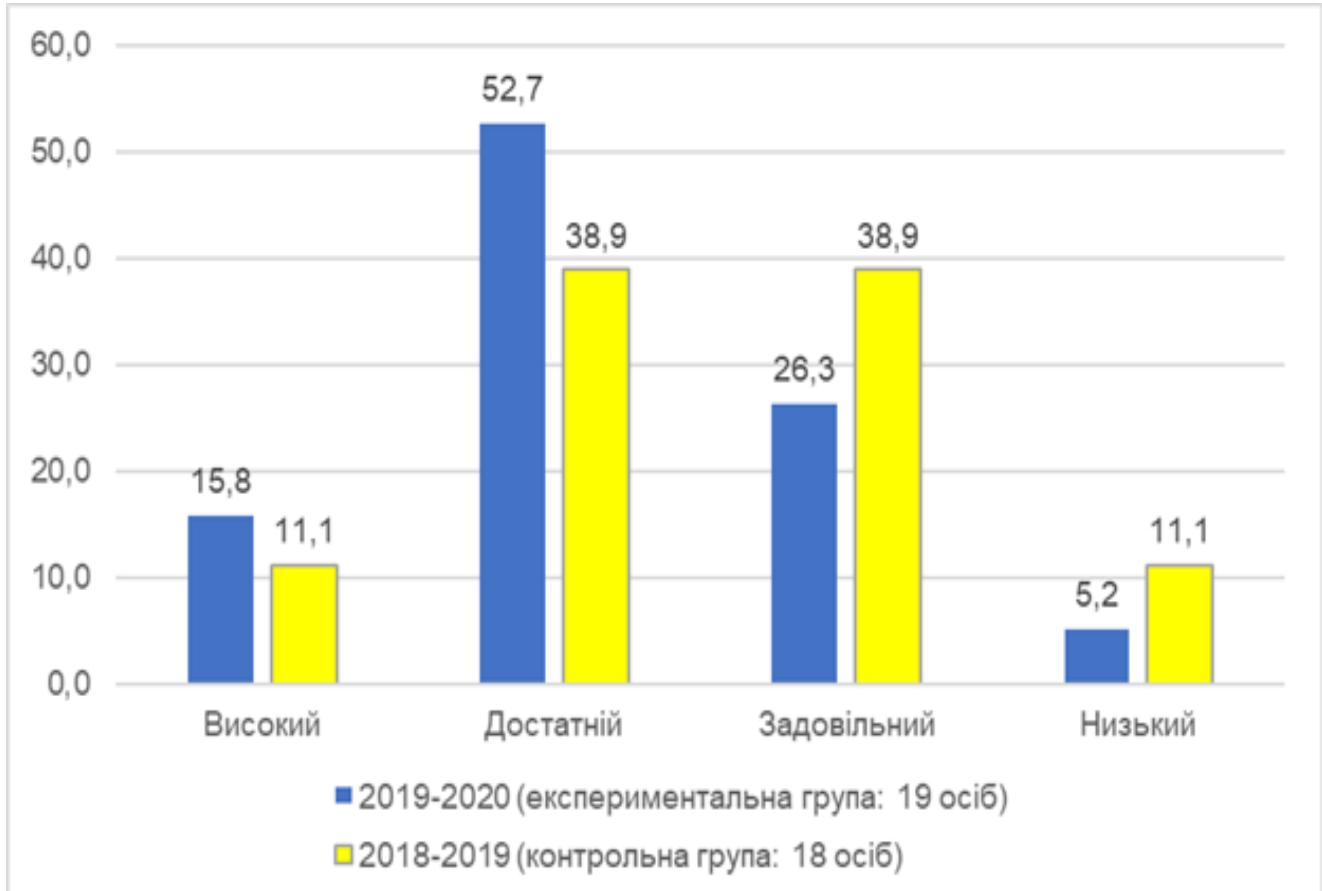

Рис. 8. Рівні сформованості управлінської компетентності у майбутніх менеджерів освіти на кінець експерименту

Експериментальне дослідження щодо формування управлінської компетентності майбутніх керівників закладів освіти з використанням EOC показало, що магістранти експериментальної групи мають більш високий рівень сформованості управлінської компетентності, ніж магістранти контрольної групи, приблизно на 9\%. Це дає підстави стверджувати, що використання ЕОС сприяє становленню майбутнього управлінця, розвиває його управлінські здібності, дає змогу вирішувати завдання формування управлінської компетентності у майбутніх менеджерів освіти, $є$ ефрективним засобом реалізації освітніх програм в університеті.

\section{IV Обговорення}

Проведене дослідження дало змогу встановити, що по завершенню навчання у майбутніх менеджерів освіти в умовах використання ЕОС університету рівень управлінської компетентності зріс, у них сфрормувалися чіткі уявлення про бажаний образ освітнього закладу, його місію, цілі, принципи та перспективи життєдіяльності.

Майбутні управлінці засвоїли систему знань, поглядів та уявлень про управлінську діяльність; стилі, форми та методи управління педагогічним колективом; навчилися визначати можливості EOC закладу для успішної управлінської діяльності, проектувати таку модель освітнього закладу, яка б характеризувалася високою управлінською культурою; оцінювати міру стабільності закладу освіти, його конкурентоспроможність, а також здатність досягати запланованих результатів в різних умовах функціонування освітньої установи.

Разом з тим, результати нашого дослідження, показали, що EOC має потужний потенціал для формування управлінських компетентностей майбутнього менеджера освіти, якщо професорськовикладацький склад університету разом із здобувачами освіти буде працювати над його розвитком та в повній мірі використовувати можливості ІКТ.

\section{V Висновки}

У зв'язку зі входженням України у глобальний економічний простір відбуваються постійні зміни, ускладняються проблеми менеджменту, загострюється конкуренція, і для забезпечення інноваційного прориву в розвитку економіки України необхідний перехід на якісно новий рівень управління. Це зумовлює формування нового типу менеджерів, які мають системне, нестандартне та стратегічне 
мислення і здатні до застосування сучасної філософії управління, вільно використовують засоби ІКТ.

Менеджер освітньої установи $€$ ключовою фігурою розвитку освітнього закладу. Від того, наскільки ефективно він буде здійснювати управління залежить ефективність роботи всіх інших працівників та загалом успішність функціонування закладу. Використання EOC значно спрощує управління та надає відповідні засоби для ефективного управління. Вміння використовувати інформаційно-комунікаційні технології в професійній діяльності, вільна орієнтація в інфрормаційноосвітньому просторі та розвиток ЕОС закладу освіти повинні бути визначені як обов'язкові компоненти в структурі управлінської компетентності менеджерів освіти.

\section{Бібліографічні посилання}

1. Бондаренко Т. В. Особливості використання програмного засобу Prezi у процесі розробки навчальних презентацій. Інформаційні технології і засоби навчання, 2018. 63(1). С. 1-11. https://doi.org/10.33407/itt.v63i1.1907.

2. Брик Р. С. Використання ІКТ в управлінській діяльності освітнього закладу. Новітні інфоормаційно-комунікаційні технології в навчальному процесі: актуальні проблеми : матеріали II обласної науково-практичної Інтернет- конференції (30 листопада, 2017 р.). Тернопіль: ТОКIППО, 2017. С. 94-98. URL: https://cutt.ly/aR7sEcN (дата звернення: 05.11.2021).

3. Гребеник І. С. Формування цифррової компетентності керівників навчальних закладів. Електронне наукове фахове видання "Відкрите освітнє е-середовище сучасного університету", 2019. (6), С. 17-25. https://doi.org/10.28925/24140325.2019.6.1725

4. Закон України «Про освіту» № 2145-VIII від 05.09.2017 p. URL: https://zakon.rada.gov.ua/laws/show/2145-19 (дата звернення: 05.11.2021).

5. Кірдан О. Л. Цифррові компетентності у змісті підготовки магістрів освітньо-профресійної програми «Управління закладом освіти». Інформаційні технології в культурі, мистецтві, освіті, науці, економіці та бізнесі : матеріали Міжнародної науково-практичної конференції, 2019. Ч. 2. С. 280. URL: https://cutt.ly/IR7sZfo (дата звернення: 05.11.2021).

6. Концепція Нової української школи (27.10.2016р.). URL: https://cutt.ly/MR7u4Wm (дата звернення: 05.11.2021).

7. Освітньо-професійна програма «Управління навчальним закладом». Офіційний сайт УДПУ. URL: https://udpu.edu.ua/navchannia/osvitni-prohramy/29895 (дата звернення: 05.11.2021).

8. Рекомендації щодо впровадження змішаного навчання у закладах фахової передвищої та вищої освіти. URL: https://cutt.ly/eR7fda7 (дата звернення: 05.11.2021).

9. Стеценко Н., Ткачук Г. Формування управлінських навичок майбутніх менеджерів освіти в умовах дистанційного навчання. Науковий часопис Національного педагогічного університету імені М. П. Драгоманова. Серія 5. Педагогічні науки: реалії та перспективи. 2021. 79. T. 2. С. 135-139. URL: https://cutt.ly/kR6ky1e

10. Тимофрєєва І. Б., Мітін А. О. Цифррова компетентність майбутнього менеджера освіти: теоретичний аспект. Освітній менеджмент: теорія і практика. 2020. Вип.8. C.108-120. URL: https://cutt.ly/oR7sy2E (дата звернення: 05.11.2021).

11. Carretero Gomez S., Vuorikari R. and Punie Y. DigComp 2.1: The Digital Competence Framework for Citizens with eight proficiency levels and examples of use, EUR 28558 EN, Publications Office of the European Union, Luxembourg, 2017. URL: https://cutt.ly/aR7iqMB (дата звернення: 05.11.2021).

\section{References}

1. Bondarenko, T. V. (2018). Peculiarities of software Prezi usage for designing educational presentations. Information technologies and learning tools, 63(1), 1-11. https://doi.org/10.33407/ittt.v63i1.1907 [in Ukrainian].

2. Bryk, R. S. (2017). The Use of ICT in the management of an educational institution. Novitni informatsiino-komunikatsiini tekhnolohii v navchalnomu protsesi: aktualni problemy, II regional scientific-practical Internet conference (pp. 94-98). Ternopil, Ukrane: TOKIPPO. URL: https://cutt.ly/aR7sEcN (accessed 05.11.2021). [in Ukrainian]

3. Hrebenyk, I. S. (2019). Formuvannia tsyfrovoi kompetentnosti kerivnykiv navchalnykh zakladiv. Elektronne naukove fakhove vydannia "Vidkryte osvitnie e-seredovyshche suchasnoho universytetu", (6), 17-25. https://doi.org/10.28925/24140325.2019.6.1725 [in Ukrainian]

4. Zakon Ukrainy «Pro osvitu» № 2145-VIII (2017). URL: https://zakon.rada.gov.ua/laws/show/2145-19 (accessed: 05.11.2021). [in Ukrainian]

5. Kirdan, O. L. (2019). Tsyfrovi kompetentnosti u zmisti pidhotovky mahistriv osvitno-profesiinoi prohramy «Upravlinnia zakladom osvity». Informatsiini tekhnolohii v kulturi, mystetstvi, osviti, nautsi, ekonomitsi ta biznesi : Mizhnarodna naukovopraktychna konferetsiia, Vol. 2, 280. Vydavnychyi tsentr KNUKiM, Kiyv, Ukraine. URL: https://cutt.ly/IR7sZfo (accessed 05.11.2021). [in Ukrainian]

6. Kontseptsiia Novoi ukrainskoi shkoly (2016). URL: https://cutt.ly/MR7u4Wm (accessed 05.11.2021). [in Ukrainian]

7. Osvitno-profesiina prohrama «Upravlinnia navchalnym zakladom». Ofitsiinyi sait UDPU. URL https://udpu.edu.ua/navchannia/osvitni-prohramy/29895 (accessed 05.11.2021). [in Ukrainian]

8. Rekomendatsii shchodo vprovadzhennia zmishanoho navchannia u zakladakh fakhovoi peredvyshchoi ta vyshchoi osvity. URL: https://cutt.ly/eR7fda7 (accessed 05.11.2021). [in Ukrainian] 
9. Stetsenko, N., Tkachuk, H. (2021). Formuvannia upravlinskykh navychok maibutnikh menedzheriv osvity v umovakh dystantsiinoho navchannia. Naukovyi chasopys Natsionalnoho pedahohichnoho universytetu imeni M. P. Drahomanova. Seriia 5. Pedahohichni nauky: realii ta perspektyvy, 2(79), 135-139. URL: https://cutt.ly/kR6ky1e (accessed 05.11.2021).

10. Tymofieieva, I. B., Mitin, A. O. (2020). Tsyfrova kompetentnist maibutnoho menedzhera osvity: teoretychnyi aspekt. Osvitnii menedzhment: teoriia i praktyka, 8, 108-120. URL: https://cutt.ly/oR7sy2E (accessed 05.11.2021). [in Ukrainian]

11. Carretero Gomez, S., Vuorikari, R., Punie, Y. (2017). DigComp 2.1: The Digital Competence Framework for Citizens with eight proficiency levels and examples of use, EUR 28558 EN, Publications Office of the European Union, Luxembourg. URL: https://cutt.ly/aR7iqMB (accessed 05.11.2021).

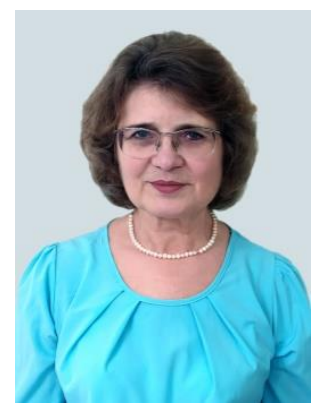

\section{Стеценко Надія Миколаївна}

Кандидат педагогічних наук, доцент, доцент кафедри педагогіки та освітнього менеджменту, Уманський державний педагогічний університет імені Павла Тичини, вул. Садова, Умань, 20300.

Тел. +380969169399. E-mail: stecenkonm@gmail.com

\section{Stecenko Nadiia Mykolayvna}

Cand. Sc. of Pedagogical Sciences, Associate Professor ,

Associate Professor at the Department of Pedagogy and Educational Management, Pavlo Tychyna Uman State Pedagogical University, str. Sadova, 28, Uman, Cherkassy region, Ukraine, 20300. Phone: +380967603913. E-mail: stecenkonm@gmail.com

ORCID: https://orcid.org/0000-0002-9802-6529

Researcher ID: https://publons.com/researcher/1760661/nadia-stecenko/

Scopus ID: https://www.scopus.com/authid/detail.uri?authorld=57219988925

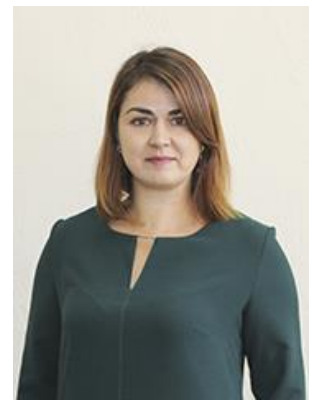

Ткачук Галина Володимирівна

доктор педагогічних наук, доцент, профресор кафедри інформатики і інформаційно-комунікаційних технологій, Уманський державний педагогічний університет імені Павла Тичини, вул. Садова, Умань, 20300.

Тел. +380969169399. E-mail: tkachuk.g.v@udpu.edu.ua

\section{Tkachuk Halyna Volodymyrivna}

Doctor of Pedagogical Sciences, Docent,

Professor at the Department of Informatics and Information and Communication Technology

Pavlo Tychyna Uman State Pedagogical University,

str. Sadova, 28, Uman, Cherkassy region, Ukraine, 20300.

Phone: +380969169399. E-mail: tkachuk.g.v@udpu.edu.ua

ORCID: https://orcid.org/0000-0002-6926-1589

Researcher ID: https://publons.com/researcher/1773042/halyna-tkachuk

Scopus ID: https://www.scopus.com/authid/detail.uri?authorld=57219986242

\section{Citation (APA):}

Stetsenko, N., Tkachuk, H. (2021). Study of managerial competence of future education managers in the context of using electronic educational environment. Engineering and Educational Technologies, 9 (4), 35-46. doi: https://doi.org/10.30929/2307-

9770.2021 .09 .04 .03

\section{Цитування (ДСТУ 8302:2015):}

Стеценко Н. М., Ткачук Г. В. Дослідження управлінської компетентності майбутніх менеджерів освіти в контексті використання електронного освітнього середовища / Інженерні та освітні технології. 2021. Т. 9. № 4. С. 35-46. doi: https://doi.org/10.30929/2307-9770.2021.09.04.03

Обсяг статmі: сторінок - 12; умовних друк. аркушів - 1,738. 